Српска допунска школа

у Париском региону при Министарству

просвете, науке и технолошког развоја

Републике Србије

blazenkatrivuncic@gmail.com

\title{
ДИГИТАЛНО ИЗДАВАШТВО У ФУНКЦИЈИ УНАПРЕЪЕЊА ДОПУНСКЕ НАСТАВЕ НА СРПСКОМ ЈЕЗИКУ У ИНОСТРАНСТВУ
}

Сажетак: У раду се даје приказ интернет странице „Моја Србија - то сам jа““, која је објединила допунску наставу на српском језику у Француској, и приказ електронске базе наставних материјала допунске наставе на српском језику у иностранству „Час по час“. Предузете дигиталне активности имају информативни, маркетиншки, образовни, интерактивни и кохезиони карактер.

Кључне речи: Српска допунска школа, дигитално издаваштво, стручна сарадња.

У складу са Стратегијом развоја образовања у Србији, Национални просветни савет усвојио је Оквир дигиталних компетенција у коме се наводи да „ниво поседовања дигиталних компетенција ученика, између осталог, зависи од нивоа дигиталних компетенција наставника. Стога се од наставника очекује да поседују одговарајући ниво информатичке, информационе, дигиталне и медијске писмености, као и да у областима у којима држе наставу познају модерне концепте, методе и алате који претпостављају смислену употребу ИКТ-а““ (МПНТР 2017: 2).

Специфични услови у којима се настава на српском језику у иностранству остварује траже од наставника умеће и прилагодљивост околностима и потребама ученика, уз подразумевану стручност, почев од „компетенција за наставну област, предмет и методику наставе, за подршку развоју личности ученика, за комуникацију и сарадњу“ (ЗУОВ 2011), до дигиталних и менаџерских знања и вештина.

Пошто допунска школа окупља ученике српског порекла који често живе на великим просторним удаљеностима, а не постоји центар или 
једна школска зграда где се часови одржавају, неопходно је да информација о постојању и раду допунске наставе на српском језику доспе до што већег броја Срба у расејању. Такође, у циљу очувања континуитета и стабилности наставе, имајући у виду њен допунски карактер, потребно је да школске активности буду видљиве, а кад год је могуће и - јавне.

Непостојање јединственог, уређеног центра који би пружио информације о допунској настави на српском језику, мали број ученика који похађа часове у односу на број Срба, велика просторна удаљеност места на којима се настава изводи, хетерогени карактер група са израженим узрасним и језичким разликама, промењена перспектива изучавања српског језика, недостатак одговарајућих уџбеника и наставних средстава, неутемељена стручна континуирана сарадња наставног кадра, довели су до потребе за отварањем електронских платформи. Креирање Веб места у складу је са Законом о основном образовању, у коме се у члану 52 наводи да је „школа дужна да има своју интернет страну“(ЗУОВ 2019).

Са друге стране, интеграциони и/или асимилациони процеси у страном окружењу утичу на очување и структуру самог српског језика. Неопходан је отворен педагошки приступ, уз размену искуства из наставне праксе, спровођење истраживачких радова и упоређивање извештаја о актуелној језичкој слици конкретне наставне групе/области, а са циљем одабира и примене одговарајућих дидактичко-методичких поступака. Усвајање српског језика изван матице зависи од степена изложености говорном моделу, свакодневне употребе језика у породичној средини, укључивања у друштвено-културни живот српске заједнице, похађања наставе на српском језику у оквиру допунске школе и одржавање и неговања веза са отаџбином. Некњижевни изговор, употреба дијалекта, контактна мрежа српског и доминантног језика земље домаћина, мали број часова у оквиру допунске школе, целодневна изложеност једном говорном узусу чине да су сви наведени фактори недовољни да се заустави процес деградације српског језика.

Будући да је „образовна пракса сложена и променљива и да се одвија кроз динамичну спрегу међусобних односа и различитих активности у социјалном и физичком окружењу, у јединственом контексту конкретне групе ученика и заједнице у којој деца живе“, Правилником остваривању образовно-васпитног рада у иностранству дају се препоруке за планирање наставе, која ће обезбедити „сигурну, подстицајну и подржавајућу средину за учење“. Дакле, „могуће је и потребно бирати садржаје и методе рада којима се стварују ситуације погодне да се ученик води кроз зону наредног развоја у различитим областима знања и 
функционисања“ (Правилник 2018). Стога је стручна сарадња, размена професионалних искустава, идеја и предлога за унапређивањем образовне праксе на српском језику у иностранству неопходна међу наставницима који су ангажовани у истој земљи, али и широм света. Настава је интегративно-корелативна и представља јединствени и сложени процес, уско повезан са ваннаставним активностима, које се на ток учења надовезују, надграђују га, и у одређеном смислу чине круну самог наставног процеса, а у спрези са културним и конфесионалним животом српске заједнице у расејању.

У дигиталној умрежености кроз сарадњу у изграђивању интернет страница пронађени су модели подршке развоју допунских школа. Електронско издаваштво препознато је као неопходно средство којим се може пружити:

- Информативност,

- Видљивост свих активности допунске наставе,

- Размена одговарајућих дидактичко-методичких прилога и

- Стручно повезивање наставног кадра.

Покренута је интернет страница „Моја Србија - то сам ја“ (srpskipariz.weebly.com) која је објединила допунску наставу у Француској од 2015, а затим и електронска база наставних материјала допунске наставе на српском језику у иностранству „Час по час“(caspocas.weebly. com) од 2016. године.

Интернет страница показује одличну комуникацију међу свим наставницима који остварују образовно-васпитни рад на српском језику у Француској и представља ризницу извештаја, репортажа, филмова и фотографија. Повезана је са школском Фејсбук страницом, преко које се могу пратити све актуелности, и која омогућава најаве догађаја и брзи проток вести.

База наставних материјала „Час по час“ основана је са циљем да се унапреди наставна пракса и да се око 50 наставника широм света, који изводе наставу на српском језику у Швајцарској, Немачкој, Француској, Италији, Грчкој, Белгији, Норвешкој, Данској, Финској, Великој Британији и Јужноафричкој Републици, повеже и размени примере добре праксе.

Дигитално издаваштво у нашем случају има маркетиншки, информативни, образовни, интерактивни и кохезиони карактер.

Сајт допунске наставе у Француској пружа информације о местима и терминима одржавања наставе, омогућава видљивост разноврсних ваннаставних активности, међународних смотри, ђачких радова, култур- 
них манифестација, плаката, најава, извештаја и репортажа. Електронске укрштенице, електронске ћириличне књиге, интерактивни пројекти, истраживачки радови о актуелном језичком стању, уз доступност других корисних линкова, значајни су и у културолошком смислу. Интернет страница је допринела повећању броја ученика у Француској. Поређење података из годишњих извештаја у Париском регону показује да је од септембра школске 2015/16. до јуна 2018/19. забележено удвостручење броја ученика и повећање броја предавача - са 2 на 5 наставника. Такође, страница представља електронску архиву четворогодишњих активности допунске школе. Она је својеврсна културолошка база радова и догађаја и представља допринос развијању свести о важности очувања српског језика и писма.

Циљ основног образовања и васпитања у расејању, ,развијање свести о сопственом националном и културном идентитету учењем српског језика и упознавањем са највреднијим делима српске културне баштине, као и подстицање одржавања трајних веза са отаџбином“ (Правилник $2108)$, налази своје остварење и у виртуелном облику. Преко наше електронске странице доступан је пројекат, којим су повезана српска допунска одељења у Француској са ђацима у редовним школама у Србији који уче француски као други страни језик. Пројекат „Образовни круг“ је дигиталног карактера, усмерен на вршњачко учење у билингвалној комуникацији, уз коришћење савремених електронских алата у истраживању и представљању тема из историје, културе и спорта. Електронска страница, а са њом повезана социјална мрежа, пружају увид у снимљене сусрете/ заједничке часове, а могу се преузети и погледати мултимедијални истраживачки ученички радови, телевизијске и радио-емисије посвећене праћењу и реализацији пројекта.

Угледни часови са интерактивним прилозима и материјалима у Ворду у бази наставних материјала допунске наставе на српском језику у иностранству омогућавају наставницима преузимање, размену и прилагођавање методичко-дидактичких радова различитим нивоима говорења српског језика и потребама одређене групе. Платформа садржи информације о актуелним конкурсима и смотрама, извештаје са одржаних стручних семинара и друге корисне линкове са наставним материјалима, а наставник може ученике упутити на самосталан (додатни) рад. Колекција часова је и полазиште на основу кога је у будућности могуће израдити дигитални уџбеник.

Банери интернет страница доступни су на званичним сајтовима Амбасаде Републике Србије у Паризу, Културног центра Србије у Пари- 
зу, а од марта 2018. и на страници „Образовно-васпитни рад на српском језику у иностранству“, која се налази на сајту Завода за унапређивање образовања и васпитања у Београду.

Доборобит дигиталног издаваштва је у драгоценој помоћи наставном кадру који се смењује и коме је омогућен стварни увид у динамичну и променљиву перспективу изучавања српског језика код млађих генерација исељеничких српских породица, што води и променама у методологији рада.

Описане предузете активности, чији је алат ИКТ, а крајњи циљ повећање броја ученика и испуњење циљева допунске наставе на српском језику, представљају једну од стратегија којом се може утицати на одржавање континуитета и стабилности наставе, као и на подизање свести говорника српског језика о важности очувања језичког идентитета и унапређења језичког понашања.

Размена искуства о настави на српском језику ван граница Србије међу земљама у којима се настава одвија, са циљем проналажења механизама који би могли утицати на изражену асимилацију српског народа и деловати у правцу очувања језика и писма, неопходна је на свим нивоима.

Српска допунска школа чини један од стубова националног идентитета Срба у иностранству. Њена стабилност зависи у великој мери од проналажења начина да се одговори задацима савремене наставе и потребама модерног ученика, који се развија у специфичном иностраном окружењу. Дакле, описане предузете активности могу бити један од модела рада, на основу кога би се покренуле друге идеје, што би, у свеукупности, водило успешно ка циљу - неговању младих српских изданака.

Очекује се да ће се после четворогодишњег рада на бесплатној платформи Вибли, који је започет и реализован као идеја појединца, рад у наредном периоду наставити у оквиру плаћеног домена, који ће омогућити брзу претрагу и допринети популаризацији српске допунске школе. Уз обуку нових наставника и укључивање у изградњу платформи, подстицаће се раст и развој допунске наставе на српском језику у иностранству.

\section{Извори и литература}

Завод за унапређивање образовања и васпитања, Република Србија (Београд). Стандарди компетенција за професију наставника и њиховог професионалног развоја. Београд: 2011. 
авод за унапређивање образовања и васпитања, Република Србија (Београд). Примена информационо-комуникационих технологија у настави. Београд: 2014.

Завод за унапређивање образовања и васпитања, Република Србија (Београд). Закон о основном образовању и васпитању. Службени гласник Републике Србије, бр. 55/2013, 101/2017, 27/2018 - др. закон и10/2019. Веб. 15. 2. 2019.

Завод за унапређивање образовања и васпитања (Београд). Правилник о стандардима компетенција за професију наставника и њиховог професионалног развоја. Службени гласник Републике Србије - Просветни гласник, бр. 5/2011-147. Веб. 3. 3. 2016.

Креирање веб-сајтова. Вебциклопедија - каталог веб-алата. Веб. 29. 4. 2017.

Министарство просвете, науке, технолошког развоја Републике Србије. Оквир дигиталних компетенција - Наставник за дигитално доба. Београд: 2017. Веб. 3. 4. 2017.

Моја Србија - то сам ја: http://srpskipariz.weebly.com/

Правилник о остваривању образовно-васпитног рада у иностранству. Службени гласник Републике Србије, бр. 28/2018. Веб. 12. 4. 2018.

Час по час: http://caspocas.weebly.com/

\section{Blaženka Trivunčić}

Serbian Supplementary School

in the Paris Region at the Ministry of Education,

Science and Technological Development

of the Republic of Serbia

blazenkatrivuncic@gmail.com

\section{DIGITAL PUBLISHING IN THE FUNCTION OF DEVELOPMENT OF COMPLEMENTARY EDUCATION IN SERBIAN LANGUAGE IN FOREIGN COUNTRIES}

\footnotetext{
Summary: The website "My Serbia - it's me” („Моја Србија - то сам ја”, srpskipariz.weebly.com) was created, which contributed to the promotion of supplementary education in the Serbian language in France since 2015, and after that then an electronic teaching materials base abroad "Lesson for lesson” („Час по час", caspocas.weebly.com) from 2016. Digital publishing in our case has a marketing, informative, educational, interactive and cohesive character. The exchange of demo lessons among 50 teachers in 11 countries is enabled, and the banners are located on the official websites of our Embassy in Paris, the Cultural Center of Serbia in Paris and the Institute for the improvement of education in Belgrade. The correlative-integrative lessons with interactive content and Word materials allow teachers to download, exchange and adapt the material to different levels of speaking of Serbian language and needs of a particular group. Information on
} 
places and terms of classes, the visibility of various after-school activities, internationals competitions, students' works, cultural events, posters, announcements, reports and reportages contributed to the doubling of the number of students in supplementary education in Serbian language in Paris region. Electronic crosswords, electronic Cyrillic books, interactive projects, research works on the current linguistic situation, along with the availability of other useful links, is also important in a cultural domain. The good sides of digital publishing are valuable assistance to teachers who come to their colleagues' places and to whom is enabled a real insight into the dynamic and changing perspective of Serbian language learning in younger generations of emigrant Serb families, which also leads to changes in the methodology of teaching. The above described activities, the ICT tool, and the ultimate goal of increasing the number of students and fulfilling the goals of supplementary teaching in the Serbian language, are one of the strategies that can influence the maintenance of the continuity and stability of teaching, as well as raising the awareness of the speakers of the Serbian language about the importance of preservation language identity and the improvement of language behavior.

Keywords: Serbian supplementary school, digital publishing, professional cooperation. 